\title{
Flora Graeca on the European continent
}

\author{
H.W. Lack \\ Botanischer Garten und Botanisches Museum Berlin, \\ Freie Universität Berlin, Königin-Luise-Str. 6-8, \\ 14195 Berlin, Germany \\ h.w.lack@bgbm.org
}

\begin{abstract}
Flora Graeca is a work in ten folio volumes, published in London between 1806 and 1840. It is based on the botanical collections made by John Sibthorp during his travels in what is now Cyprus, Greece, Italy and Turkey and the pictorial documentation of the plants produced by Ferdinand Bauer. The text was written by James Edward Smith, Robert Brown and John Lindley. Flora Graeca was printed in a tiny edition with the result that many botanists considered it to be non-existent or as only a manuscript. This paper deals with the few copies of Flora Graeca kept today in libraries on the European continent and their historical backgrounds - three in Paris, one in Vienna and Darmstadt respectively, all apparently subscription copies, while the copies in St. Petersburg and Copenhagen were previously owned by Fredrick North, 5th Earl of Guildford, and John Platt. The botanical affiliations of the previous owners, among them Franz I, Emperor of Austria, and Ludwig I, Grand Duke of Hesse, are explained. The libraries on the European continent that have copies of the so-called Bohn reissue of Flora Graeca are listed. Particular attention is given to the Belgrade copy, a hybrid consisting of printed title matter with some of the landscapes copied by hand and the 966 engravings, whereas all text pages, indices and appendices have been written on a type writer.
\end{abstract}

Keywords. Copenhagen copy, Darmstadt copy, Flora Graeca, history of plant taxonomy, Paris copies, St. Petersburg copy, Vienna copy.

\section{Introduction}

When David Mabberley and I met for the first time in August 1983 in Berlin, which was then still infamous for its wall, one of our topics of conversation was the natural history illustrator Ferdinand Bauer (1760-1826). Among many other works, he had produced the 966 watercolours depicting plants which were later published as coloured copper engravings in the exceedingly rare Flora Graeca. Several more meetings followed in Oxford, Kew and elsewhere and many letters were exchanged, which were then still on paper, resulting, after many problems and delays, in the monograph The Flora Graeca Story: Sibthorp, Bauer and Hawkins in the Levant, published by Oxford University Press in 1998 (Lack \& Mabberley, 1999). Over the following years an exhibition on this subject was organised in the Bodleian Library in Oxford (Lack, 1999), and further studies appeared on this subject (e.g. Harris, 2007) culminating in four more books - two dealing with the life and work of Ferdinand (Mabberley, 1999, 2017), one with the life and work of his elder brother Franz (1758-1840) (Lack, 2008), and one more comprehensive account of the lives and works of the Bauer brothers, i.e. Joseph 
(1756-1831), Franz and Ferdinand, setting them and their numerous productions into the context of their time (Lack, 2016).

What was written in these publications on the Flora Graeca project was almost exclusively based on the archival material conserved in Oxford and the copies of the Flora Graeca kept in England. This paper does not paraphrase these earlier findings, nor does it add to them, but it analyses the very few copies of this work kept on the European continent and their varied historical backgrounds. Among these, the copies conserved in Vienna and Copenhagen were of particular importance for the history of the botanical exploration of what is now Cyprus, Greece, Italy and Turkey — regions which in the late eighteenth century by and large belonged to the Ottoman Empire. The following brief outline is mainly based on The Flora Graeca Story (see above).

\section{Flora Graeca}

Flora Graeca is a work in ten folio volumes, published in London between 1806 and 1840 in a total of twenty instalments. Each volume contains title matter (i.e. title page and frontispiece), text and one hundred coloured copper engravings (with the exception of the last volume which has only 66), with indices, appendices, etc. also placed in the final volume. Contrary to our modern concept of a Flora, Flora Graeca does not deal in a comprehensive way with the plant life of the study area, but only with a selection of it - c. 1000 plant species, all observed in the field by John Sibthorp (1758-1796), third Sherardian Professor of botany at Oxford University, in the years 1786-1787 and 1794-1795, including those recorded as pencil drawings by Ferdinand Bauer in 1786-1787. Working in Oxford, Bauer produced a pictorial documentation for the project between 1788 and 1794, including seven frontispieces which served as the basis for the production of the copper engravings (Lack, 1997). Sibthorp, meanwhile, had made no progress with the text for his intended Flora.

In his carefully worded, though very unconventional will, Sibthorp left lands in Sutton manor in the county of Oxford to his alma mater Oxford University for the endowment of a chair - but under the condition that the proceeds were first used for a precursor, the Prodromus Florae Graecae, and then for the Flora Graeca, to be published based on the collected materials. Considering the very substantial sums involved, Oxford University accepted the arrangement, but had to wait for 44 years until money was eventually available for the chair. Two facts were of decisive importance for Flora Graeca: firstly, Sibthorp's stipulation that the work was 'to consist of ten Folio Volumes each Volume to consist of one Hundred Plates ... \& I do request of my Executors to find out \& nominate some Person well skilled in Botany \& Natural History for that Purpose \& under whose direction the Plates may be engraved \& coloured from the Drawings \& MS Notes' and, secondly, by Sibthorp's careful choice of his co-executors - John Hawkins (1761-1841), his former travel companion who was to become the organiser of the foundation, Thomas Platt (d. 1842), a prominent solicitor, who would act as administrator of the foundation, and John Wenman (17451796), Regius Professor of Civil Law at Oxford University. 
The co-executors clearly subscribed to the rigid adherence to Sibthorp's will and the highest quality of the end product, which meant searching for a competent botanist who they found firstly in James Edward Smith (1759-1828), after his death to be followed briefly by Robert Brown (1773-1858), and finally John Lindley (17991865). The latter's contribution to Flora Graeca has been admirably analysed by Stearn (1999). In addition, the co-executors had to look for a qualified company capable of engraving the 966 copper plates (plus those for the frontispieces), to produce the prints and have them coloured - an immense labour. They recruited James Sowerby (17571822), later followed by other members of his family to do this job (Henderson, 2015). Last but not least, printers for the text had to be found. All this ensured the particularly high profile of literally every aspect of the Flora Graeca. However, no attempt is made here to analyse again what has already been written on the exceedingly high quality of text and illustrations.

However, there was a major financial problem: the proceeds from the Sutton manor were rather too small for Sibthorp's gigantic project, so that Flora Graeca could only be offered on the basis of a subscription, i.e. money from the subscribers had to be added to the funds from the estate to make the production of the great work possible. Right from the beginning the subscription cost was extravagant, which quite naturally reduced the number of potential buyers to the inner circle of the very rich.

\section{The lists of subscribers}

Two lists of subscribers have survived - one for the fifth fascicle with the following names: '[1] Sir J. Banks, [2] Lord Visc. Milton, [3] Col. Sibthorp, [4] J. Hawkins, Esq., [5] Platt, Esq. [6] A. B. Lambert, Esq., [7] Earl Spencer, [8] G. Hibbert, Esq. [9] Earl of Dartmouth, [10] Marquis of Stafford, [11] Prof. Martyn, [12] Mis Sherbrooke, [13] Earl of Bridgewater, [14] Sir M. Cholmeley, [15] Rev. J. Brie, [16] Lord Guildford, [17] Marquess of Bath, [18] Radcliffe Library, [19-21] M. Artaria 3 copies, [22] Sir J. E. Smith?, [23-29] foreign purchasers, [30] Trin. Coll. Library, [31] All Souls, [32] Univ. Cambridge', and a second list entitled 'Messrs Payne and Foss's distribution of the twenty-five perfect copies of the Flora graeca. Folio. - 1. Earl FitzWilliam. - 2 . J. Hawkins Esq.re. - 3. Thomas Platt Esq.re. - 4. Earl Spencer. - 5. Geo: Hibbert Esq.re. - 6. Earl of Dartmouth. - 7. Marquis of Bath. - 8. Duke of Sutherland. 9. Mr. Sowerby. — 10. Rev.d T. Bell. - 11. Mr. Bohn, Henrietta street. - 12-14. Messr. Artaria \& Fontain, Manheim, 3 copies. - 15. Messr. Deighton, Cambridge for the University Library. - 16. H. Holland Esq.re. - 17.-19. Mr. Parker, Oxford for Radcliffe Bodleian and Botanical Libraries. - 20. Mr. Rich. Red Lion square. - 21.25. Horticultural soc.-Linnean soc.-British museum, London-The Bodleian Library, and the Botanic garden, Oxford (5 copies). Delessert France Grand Duke' (Lack \& Mabberley, 1999). From the second list, only the following subscribers are relevant in our context: Messr. Artaria \& Fontain, Mannheim (3 copies), [Benjamin] Delessert, Grand Duke, i.e. Ludwig I, Grand Duke of Hesse and by Rhine, and Thomas Platt and, from the first list, Lord Guildford. 
The tiny number of copies produced resulted in a simple fact, very appropriately worded by the great bibliographer Georg August Pritzel (1814-1874) 'Das Werk [die Flora Graeca] ist von vielen Botanikern als gar nicht existent oder als Manuskript betrachtet worden' [The work [the Flora Graeca] was regarded by many botanists as non-existent or as a manuscript] (Pritzel, 1847a).

\section{The Paris copies}

Nothing underlines better the central position of Paris in the field of plant taxonomy during the first half of the nineteenth century than the fact that no less than three complete copies of the first edition of Flora Graeca were acquired by libraries in the French capital where they remain - in the Bibliothèque national de France $(\mathrm{BnF})$, in the Bibliothèque centrale $(\mathrm{BC})$ of the Muséum National d'Histoire Naturelle (MNHN) and in the Bibliothèque de l'Institut de France (BIF). No dates of acquisition for the $\mathrm{BnF}$ and the BC copies are available (C. Lim, pers. comm., 18 April 2018). Apart from a passing reference in a letter from Jean Baptiste Antoine Guillemin (1796-1842) to Augustin Pyramus de Candolle (1778-1841), dated 5 June 1834 (Hoquet, 2002), the same holds true for the BIF copy. It had been acquired by the wealthy banker, entrepreneur and Maecenas [patron] Benjamin Delessert (1773-1847), who was a kind of French Sir Joseph Banks, and had previously been kept in the Musée Botanique which Delessert had founded (Hoquet, 2014).

The Delessert copy formed the basis of the only review of the Flora Graeca published on the European continent. Its author was Michele Tenore (1780-1861), Professor of Botany at Naples University and Prefect of the Botanic Garden there, who wrote, full of enthusiasm, 'La classica terra delle scienze e delle arti, la patria di Teofrasto, Omero, Aristotile, Fidia, Prassitile, ben si meritava il dono della più magnifica Flora del mondo. Tal'è di fatti la Flora Greca del Sibthorp; sia che considerar se ne vogliano gl'illustri scienziati che vi hanno dato opera, sia per la superiorità della sua artistica esecuzione' [The classical territory of the sciences and the arts, the country of Theophrastus, Homer, Aristotiles, Phidias, Praxitiles well deserved the gift of the most splendid Flora of the world. This in fact is the Flora Graeca of Sibthorp; considering both what the illustrious scientists collaborating in this work achieved and what concerns the superiority of its artistic execution] (Tenore, 1842). However, when intending to write his review, Tenore was faced with a problem - he had to travel from Naples to Paris to study a copy. Although the work also deals with several plants found and recorded in Sicily, then part of the Kingdom of Naples, it was not available on the Apennine Peninsula. This is the reason why Tenore, who had not seen the twentieth and last instalment of Flora Graeca, which at that time was not yet available in the Musée Delessert, noted 'quest'opera sontuosissima ... inaccessibile alla quasi totalità de' botanici non si trova che in pochissime biblioteche' [this most sumptuous work ... almost inaccessible to the totality of botanists is found only in very few libraries] (Tenore, 1842). 


\section{The Vienna copies}

For about a century two copies of the Flora Graeca were kept in Vienna - in the Kaiserliche Hofbibliothek and in the Fideikommissbibliothek. With the end of Habsburg rule the former library became the Österreichische Nationalbibliothek (ONB) and the latter was amalgamated with it (Huber-Frischeis et al., 2015). As a consequence, the Hofbibliothek copy (shelf mark 200.B.1) was deaccessioned after 1935 and its current whereabouts remains unknown (M. Ortner, pers. comm., 30 December 2016); it is not dealt with here any further. By contrast, the Fideikomissbibliothek copy (former shelf mark Franz 19584) survived and received the new shelf mark 181.472-E.Rara.

The library, which later became known as Fideikommissbibliothek, had been initiated in c. 1784 by Franz [Francis], Archduke of Austria (1768-1835), although no formal document concerning its foundation is known to exist (Huber-Frischeis et al., 2015). In 1792 Franz succeeded his father Leopold II as Franz II, Emperor of the Holy Roman Empire, and had himself proclaimed Franz I, Emperor of Austria in 1804. With the end of the Holy Roman Empire in 1806 the previous title was no longer used. After his death his eldest son and successor on the throne, Ferdinand I, Emperor of Austria (1793-1875), became the beneficiary of the Fideikommissbibliothek and subsequently the latter's younger brother Archduke Franz Karl (1802-1878). He was followed by his son Franz Joseph I, Emperor of Austria (1830-1916). When the latter died, his grandnephew Karl I, Emperor of Austria (1887-1922), succeeded him and incidentally was the last of the line. Of all members of the Habsburg family only Franz I was a dedicated bibliophile who spent vast sums on his library and it was also he who had created the fidei commissum, as a matter of fact on the very day before he died.

The first five instalments of Flora Graeca were acquired for Franz I at the auction of the library of Prince Prosper von Sinzendorf(1751-1822), another bibliophile if not actually a bibliomaniac (Huber-Frischeis \& Knieling, 2015). He was a member of the upper echelons of the aristocracy enjoying imperial immediacy, and owned estates in what is now Austria, the Czech Republic and Germany though he lived mainly in Ernstbrunn castle in the Archduchy of Austria below the river Enns. This is also the place where he kept his exquisite library (Huber-Frischeis \& Knieling, 2015). In April 1823 Peter Thomas Young (1764-1829), who was at that time the principal librarian of Franz I's private library, informed his superior that rare books could be acquired at the auction of Sinzendorf's library at a significantly lower price than on the book market. With Franz I's consent, Mathias Artaria (1793-1835), a son of Domenico Artaria based in Mannheim, took part in the auction and purchased 17 books, among them the first five instalments of Flora Graeca for 120 fl. 24 kr. C. M. (Huber-Frischeis \& Knieling, 2015). Apparently, they did not receive a bookplate, stamp or other mark of ownership from Sinzendorf.

When selling the five instalments to Franz I, Artaria had wisely not asked for a fee (Huber-Frischeis \& Knieling, 2015). This may have been a motive for choosing him in early 1828 to deliver the next two instalments for no less than $333 \mathrm{fl} 20 \mathrm{kr}$. C.M. (for the subsequent four instalments see 'Botanical affiliations').

Ferdinand I, Emperor of Austria, also showed botanical interests and had the subscription of the Flora Graeca continued. 


\section{The Darmstadt copy}

Almost nothing is known about the acquisition of the copy of Flora Graeca that is kept in the Universitäts- und Landesbibliothek Darmstadt (Schneckenburger, 2015; Schneckenburger et al., 2016). Almost certainly the note 'Grand Duke' in the second list of subscribers refers to Ludwig I, Grand Duke of Hesse (1753-1830). The complexities of central European history are mirrored in his titles. Succeeding his father Ludwig IX, reigning landgrave of Hesse-Darmstadt, he first became Ludwig $\mathrm{X}$, then, with the foundation of the Confederation of the Rhine in 1806, Ludwig I, Grand Duke of Hesse, and as a consequence of the Congress of Vienna in 1816 he became Ludwig I, Grand Duke of Hesse and by Rhine. He was a bibliophile and promotor of the arts and sciences who also had the Grand Ducal Library made public (Schneckenburger, 2015). Like Emperor Franz I and Delessert he also bought the exceedingly rare 'Hortus semper virens' [The evergreen garden] by Johann Simon von Kerner (1755-1830) (Pritzel, 1847b; Hoquet, 2002; Schneckenburger et al., 2016). This is an extravagantly expensive work allegedly called by Young in Vienna 'Hortus semper vorans' [The ever-devouring garden] (Pritzel, 1872). The Darmstadt copy of the Flora Graeca is unique since 18 of the 20 instalments are still in their original covers while only two were bound (Schneckenburger, 2015). Ludwig I was succeeded by his eldest son Ludwig II, Grand Duke of Hesse and by Rhine (1777-1848), who continued the subscription of Flora Graeca.

\section{The St Petersburg copy}

The Biblioteka Botaničskogo Instituta im. Komarova of the Rossiskaja Akademija Nauk [Library of the Komarov Botanical Institute, Russian Academy of Sciences] in St Petersburg keeps another copy of the Flora Graeca. Despite suggestions to the contrary (Lack, 2015), the St. Petersburg copy was not subscribed by Alexei Kirillovich Razumovsky (1748-1822), minister of national education in St. Petersburg. Instead the first eleven instalments were acquired at the sale of the library owned by Fredrick North, 5th Earl of Guildford (1766-1827), a fact recorded in a report on the institution's library (Nadsona, 1913). This is corroborated by an earlier report in the St. Petersburger Zeitung (Berg, 1853), a daily published by the Imperial Academy of Sciences in St. Petersburg, and North's bookplate glued on the inner side of the front book cover and information from the library's accession book (D. Geltman, pers. comm., 24 April 2018). A London-based agent of the Imperial Botanical Garden in St. Petersburg had arranged for this acquisition (Berg, 1853), while the last seven instalments were acquired from the publisher. Photographs of the frontispiece of volume 8 and of the spines of all ten volumes were published relatively early on (Nadsona, 1913).

North had studied at Eton and Christ Church, Oxford, was elected a Fellow of the Royal Society in 1794, and unexpectedly inherited the earldom in 1817. Like Lord Byron, an enthusiastic and eccentric devotee of Greek and Italian culture, he 
promoted a scheme for the foundation of an Ionian University. In 1824 North became its first chancellor when the university was inaugurated in Corfu, then under British control. For a philhellene like him, the purchase of the Flora Graeca must have been something very close to his heart.

\section{The Copenhagen copy}

The copy kept in Det Kongelige Bibliotek in Copenhagen is a very recent acquisition, though with a remarkable background.

Under the will of George Claridge Druce (1850-1932), who had served on the Oxford City Council and as Mayor of Oxford, his particularly fine copy of the Flora Graeca, previously owned by Platt, passed to Oxford University (Anonymous, 1943). At that time Oxford University already possessed three copies: a subscription copy (in the Radcliffe Library) and two presentation copies - in the Bodleian Library and in the library of the Botanic Garden (Anonymous, 1943), the latter now called the Sherardian Library (shelf mark: Sherard 761). This copy carries the note 'Decem hæc volumina inter libros bibliothecæ horti botanici Oxoniensis Johannis Sibthorp. M. D. testamenti curatores Johannes Hawkins et Thomas Platt perpetuo servari voluerunt A.D. MDCCCXL.' [These ten volumes have been permanently deposited among the books of the library of the Oxford botanic garden by John Hawkins and Thomas Platt, executors of Dr John Sibthorp's will. 1840].

Oxford University therefore decided to sell two of its four copies for the benefit of the Druce Fund - the Bodleian copy with plate 251 missing, and the Radcliffe copy (Anonymous, 1943). This resulted in the Druce copy now being shelved in the Bodleian Library (shelf mark Arch. AA a. 25).

While nothing seems to be known about the fate of the deaccessioned Bodleian copy, the Radcliffe copy must have been sold to Arthur Quinton Wells (1896-1956), a pathologist based at Oxford (Witts, 1958), who had his bookplate glued on the inner side of the front book cover. Later this copy passed to Greve [Count] Hans Wachtmeister af Johannishus, a landowner in Blekinge in southern Sweden (A. Strid, pers. comm., 25 November 2016), who had the book plate of the Johannishus-Bibliotek affixed, again on the inner side of the front book cover (A. Toftgaard, pers. comm., 29 November 2016). Around 1989 Wachtmeister decided to sell some of his possessions, among them valuable natural history books like his copy of the Flora Graeca (A. Strid, pers. comm., 25 November 2016). Following a proposal by A. Strid, now Ørbæk, and S.-E. Sandermann Olsen (1920-2016), an apothecary and collector of botanical books in Holte, the Copenhagen-based Carlsberg Foundation acquired this copy and donated it to Det Kongelige Bibliotek in Copenhagen (A. Strid, pers. comm., 25 November 2016). The Bodleian stamp on the frontispiece of volume 1 of the Copenhagen copy proves the transfer outlined here. 


\section{Botanical affiliations}

The two sovereigns, i.e. Franz I and Ludwig I, as well as Sinzendorf, are known for their interests in botany, although they definitely did not focus their attention on the flora of the East Mediterranean area. However, detailed and ample records are only available for Franz I (e.g. Pfundheller, 1881; Riedl-Dorn, 1989; Lack, 2006) who seems to have even inspected his copy of Flora Graeca. On 15 April 1828 Young reports to his master that he, i.e. Emperor Franz I, had at the moment instalments 10-11 of Flora Graeca in 'Ah. Händen' [his highest of all hands], instalments for which an invoice had been received from Mathias Artaria (Young to Franz I, 15 April 1828). Maybe Franz I had a particular interest in the copper engravings of Flora Graeca based on the watercolours by Ferdinand Bauer, as less than two years before, on 3 September 1826, Franz I had agreed to purchase the natural history materials and drawings of Ferdinand Bauer from the latter's estate for no less than 1500 fl. C.M. (Lack, 2002); this material is now kept in the Naturhistorisches Museum in Vienna. Franz I's interest in the Flora Graeca persisted until late in his life-on 24 February 1834, just a year before his death, he agreed to have an invoice from Artaria \& Fontaine, Mannheim for two further instalments paid (note in a letter of Leopold von Khloyber to Franz I, 21 January 1834).

Much less is known about Ludwig I and Sinzendorf. Ludwig's associations with botany are at best meagre. However, he agreed to the foundation of a botanical garden proposed by his librarian and botanist Johannes Hess (1786-1837) (Schneckenburger et al., 2016). Work started in 1814 with the lay-out of the garden in the moat of the ducal residence in Darmstadt (Esselborn, 1979). By contrast, Sinzendorf's conservatories in Ernstbrunn and his collections of aristolochias and bignonias are explicitly mentioned in a poem of 1799 by Joseph von Hammer (later Freiherr von Hammer-Purgstall) (Hammer, 1812) with the conservatories also documented in a plan dated 1835 (Hajós, 1989).

Delessert had founded a private botanical institute very appropriately called Musée Delessert (Lasègue, 1845), which subsequently passed to his brother FrançoisMarie Delessert (1780-1868). After the latter's death, the collections were split up, with the fine botanical library being acquired by the Institut de France (Hoquet, 2002).

Druce, a pharmaceutical chemist and owner of the chemist's shop Druce \& Co., High Street, Oxford, had strong botanical interests. He published several Floras of the Thames Valley counties, i.e. a Flora of Oxfordshire (Druce, 1886), Flora of Berkshire (Druce, 1898) and Flora of Buckinghamshire (Druce, 1926). In 1895 he was appointed Curator of the Fielding Herbarium of Oxford University and attached to Magdalen College (Rendle, 1932).

Wells was chairman of the curators of the Botanical Garden of Oxford University with hobbies that included 'Alpine plants which he sought out in Greece, Spain and France' (Witts, 1958), while Greve Hans Wachtmeister af Johannishus, another amateur botanist, first came in contact with A. Strid at a meeting of the Lund Botanical Society (A. Strid, pers. comm., 20 November 2016). 


\section{Copies relevant for the history of plant taxonomy}

Because of their relevance for the history of plant taxonomy, two copies of Flora Graeca stand out. The Vienna copies became the standard of reference for all those students of the flora of the East Mediterranean based in the Austrian capital - and the list is a long one. Their main works - Theodor Kotschy's account on the flora of Cyprus in Die Insel Cypern (Kotschy, 1865), the Conspectus Florae Graecae (Hálacsy, 1900-1904) and the Prodromus Florae Peninsulae Balcanicae (Hayek, 1924-1933) - are full of references to the Flora Graeca. However, no one knew the copy kept in the Österreichische Nationalbibliothek better than Karl Heinz Rechinger (1906-1998), the author of Flora Aegaea (Rechinger, 1944), connoisseur of the flora of the East Mediterranean and the Near East, who arranged for a long-term loan of the ten volumes to the library of the Naturhistorisches Museum in Vienna.

Similarly, Arne Strid became the specialist on the Copenhagen copy. Before its acquisition by the Carlsberg Foundation he had arranged for the text and illustrations of all ten volumes to be photographed (A. Strid, pers. comm., 20 November 2016). This material subsequently became the basis for the re-issue of the illustrations of Flora Graeca in reduced format with current scientific plant names, synonyms, new descriptions, miscellaneous notes and distribution maps added (Strid \& Strid, 20092013).

All copies of the Flora Graeca dealt with in this contribution so far belong to the first edition, a sheet starting with the line 'Lectori benevolo' in the tenth volume being regarded as the shibboleth - it is always present in the first edition, but missing in the so-called second impression. Pigments and watermarks differ (see below), though these are much more tedious to analyse - for pigments expert knowledge is necessary and for watermarks several hundred sheets of paper have to be studied.

\section{Bohn's so-called second impression and the Belgrade copy}

At the suggestion put forward by Sir William Hooker (1785-1865), the first director of the Royal Botanic Gardens, Kew (Lack \& Mabberley, 1999), and with the involvement of Charles Giles Bridle Daubeny (1795-1867), professor of chemistry and botany at Oxford University (Pritzel, 1847a; Berg, 1853), a second impression of Flora Graeca was produced by Henry Bohn (1796-1884) in London. However, considerable doubts exist if this is an appropriate term in this context. Considering the low price Bohn asked for the so-called second impression (see below) it has been hypothesised that he 'took over the remaining stock, which would have included the printed text, a certain number of plates, the engraved coppers for the plates and a set of plates hand coloured to serve as patterns for the coloration' (Swann, 1972). Indeed, this may have been the case (Lack \& Mabberley, 1999), but what Bohn had taken over must have also included the printing forms for the text, title matter, etc. These he left completely unaltered not even the publication dates given on the title pages were changed. Judging from the post-1840 watermarks on several sheets of the so-called second impression, what was 
missing in the stock taken over by Bohn must have been printed on new paper using the printing forms in order to create complete copies for sale. This state of affairs is corroborated by the Göttingen copy (see below).

Complete sets were offered by Bohn for only $£ 63$ in 1847 (Pritzel, 1847a; Berg, 1853), a much lower price than the subscription price for the first impression, but no attempt to deal with these in detail is made here. Again, the edition was very small, about 40 copies, sold to the general public (Swann, 1972; Lack \& Mabberley, 1999). Three have survived in libraries in what is now Germany, in the Niedersächsische Staats- und Universitätsbibliothek Göttingen, the Universitätsbibliothek Leipzig, and the Württembergische Landesbibliothek Stuttgart (Schneckenburger et al., 2016). A closer analysis of the Göttingen copy has shown that it consists of sheets of the first and the so-called second impression (Wagenitz, 1982), differing significantly in the watermarks and therefore best regarded as a chimaera. The Leipzig copy was the subject of a detailed review (Pritzel, 1847a); however, it was surprisingly not recognised as belonging to so-called second impression in a recent catalogue (Schneider \& Vieler, 2014). Several more copies of this 'Bohn edition' are known from other countries on the European continent, e.g. in Greece the copy in the Gennadeios Bibliotheki in Athens (Georgopoulou, pers. comm., 30 November 2016), in Italy the copy in the Biblioteca dell'Orto Botanico dell' Università degli studi di Padova, and in Switzerland the copies in the Universitätsbibliothek Basel and the Conservatoire et Jardin Botaniques in Geneva. For all these copies no in-depth analysis of the water-marks is available. The final stock of Bohn's second edition is stated to have been taken over by Bernhard Quaritch (1819-1899), another prominent antiquarian and book dealer in London, who reported to have offered his 'last copy' about 1880 for sale and noted 'the coppers were recently sold as metal' (Swann, 1972).

No copy of Bohn's second impression exemplifies in a more convincing way the prestige and status of Flora Graeca for plant taxonomy than the copy kept in the Biblioteka Botanički Bašti Jevremovac, Universitet u Beogradu [Library of the Botanical Garden Jevremovac, Belgrade University]. Bound in ten volumes, it turns out to be a hybrid consisting of (1) printed title matter, some evidently at proof stage, (2) the frontispieces, and (3) the 966 copper engravings, whereas (4) all text pages, (5) the indices and (6) the appendices were copied with a typewriter. Additionally, the words in Greek letters were added by hand. The typed note 'Pinxit et abscipsit [sic] anno 1903-1905 Rudolphus Simkó. Posonium' [Painted and copied in the years 1903-1905 Rudolf Simkó. Pozsony, i.e. Bratislava] at the end of volume 10 explains the background and origin of this copy which must have been extremely tedious and labour-intensive to produce. 'Pinxit' refers to the fact that the several landscapes forming part of the frontispieces were painted by Simkó, which is corroborated e.g. by his note in Hungarian 'Másolta Simkó R. 1904' [copied R. Simkó 1904] written in ink on the margin of the landscape being an element of the frontispiece for volume 3 . However, this may not be the full story, since the final page of volume 9 carries the hand-written note 'Scripsit anno 1895 Die 4 / IV. Rudolphus Simkó' [Written on 4 April 1895 Rudolf Simkó]. Nothing is known about this copyist evidently working for years in what is now Bratislava (K. Marhold, pers. comm., 15 May 2017). According 
to the inventory book the Botanical Garden Jevremovac bought this very special copy for 116.000 dinars from Géza [Geca, Gelia] Cohn [Kon] (1873-1941), an antiquarian, book dealer and publisher based in Belgrade (Köstner, 2005), in 1926.

It is very good to know that the authorities of Belgrade University seem to be aware of the value of this copy — in the recent volume 'Universitetsko Nasleđe Srbije / The University Heritage of Serbia' (Lazović et al., 2017) an image showing the frontispiece of volume 1 has been included.

\section{Epilogue}

Over recent decades interest in the Flora Graeca has increased significantly on the European continent. No doubt this is largely due to several recent publications (see introduction) and the fine reissue in reduced size with ample commentaries (Strid \& Strid, 2009-2013). Exhibitions dedicated to the great work or including it — in Athens, Darmstadt (Schneckenburger et al., 2016), Göttingen (Wagenitz, 1982), Leipzig (Schneider \& Vieler, 2014) and Vienna (Lack, 2016) - contributed to this rise in public awareness. However, of these only the Darmstadt and the Vienna copies belong to the first impression and it is the former, together with the copy in the Sherardian Library at Oxford, which are now freely available for study on the internet.

ACKNOWLEDGEMENTS. Thanks are due for personal information provided by A. Catterall (Oxford), D. Geltman (St. Petersburg), M. Georgopoulou (Athens), M. Kiegler (Vienna), C. Lim (Paris), K. Marhold (Bratislava), M. Ortner (Vienna), A. Strid (Ørbæk), A. Toftgaard (Copenhagen), S. Vukojičić (Beograd), S. Wheale (Oxford). J. Compton (Tilsbury), E. Lack (Berlin) and A. Strid kindly read a preliminary version of this text.

\section{References}

Anonymous (1943). Sibthorp's 'Flora Graeca'. Bodleian Libr. Rec. 2: 75-76.

Berg, E. von (1853). Notiz über die Flora Graeca Sibthorpiana. St. Peterb. Zeit. 1853: 248.

Druce, G.C. (1886). The flora of Oxfordshire. London: Parker and Co.

Druce, G.C. (1898). The flora of Berkshire. Oxford: Clarenden Press.

Druce, G.C. (1926). The flora of Buckinghamshire. Arbroath: T. Buncle \& Co.

Esselborn, K. (1979). Johannes Hess. In: Hessische Lebensläufe 3, pp. 196-199. Darmstadt: Hessische Historische Kommission.

Hajós, G. (1989). Romantische Gärten der Aufklärung. Englische Landschaftskultur des 18. Jahrhunderts in und um Wien. Stud. Denkmalschutz Denkmalpflege 14. Wien: Böhlau Verlag.

Hálacsy, E.v. (1900-1904). Conspectus florae graecae 1-3. Lipsiae: G. Engelmann.

Hammer, J.v. (1812). Gedicht über die Wiener Gärten besungen im Jahr 1799. In: Mahlerisches Taschenbuch für Freunde interessanter Gegenden-Natur und Kunst-Merkwürdigkeiten der Österreichischen Monarchie, pp. 5-80. Wien: Anton Doll. 
Harris, S. (2007). The magnificent Flora Graeca: How the Mediterranean came to the English garden. Oxford: Bodleian Library.

Hayek, A.v. (1924-1933). Prodromus Florae peninsulae Balcanicae. Repert. Spec. Nov. Regni Veg. Beih. 30.

Henderson, P. (2015). James Sowerby. The enlightenment's natural historian. Kew: Royal Botanic Gardens, Kew.

Hoquet, T. (2002). La bibliothèque botanique de Benjamin Delessert. Bull. Bibliophile 1: 100104.

Hoquet, T. (2014). Botanical authority. Benjamin Delessert's collections between travelers and Candolle's natural method (1803-1847). Isis 105: 508-539.

Huber-Frischeis, T. \& Knieling, N. (2015). Vom Buchmarkt zum Bibliotheksbestand. Erwerbungsmechanismen und Bestandaufbau. In: Huber-Frischeis, T., Knieling, N. \& Valenta, R. (eds) Die Privatbibliothek Kaiser Franz I. von Österreich 1784-1835. Bibliotheks- und Kulturgeschichte einer fürstlichen Sammlung zwischen Aufklärung und Vormärz. Veröff. Komm. Neuere Gesch. Österr. 111, pp. 229-362. Wien: Böhlau Verlag.

Huber-Frischeis, T., Knieling, N. \& Valenta, R. (2015). Einleitung. In: Huber-Frischeis, T., Knieling, N. \& Valenta, R. (eds) Die Privatbibliothek Kaiser Franz I. von Österreich 1784-1835. Bibliotheks- und Kulturgeschichte einer fürstlichen Sammlung zwischen Aufklärung und Vormärz. Veröff. Komm. Neuere Gesch. Österr. 111, pp. 15-26. Wien: Böhlau Verlag.

Köstner, C. (2005). Das Schicksal des Belgrader Verlegers Geca Kohn. Mitt. Ges. Buchforschung Österr. 7: 7-19.

Kotschy, T. (1865). [Equisetaceae-Mimoseae]. In: Unger, F. \& Kotschy, T. (eds) Die Insel Cypern ihrer physischen und organischen Natur nach; mit Rücksicht auf ihre frühere Geschichte. pp. 173-392. Wien: W. Braumüller.

Lack, H.W. (1997). Die Frontispize von John Sibthorps "Flora Graeca". Ann. Naturhist. Mus. Wien 99B: 615-654.

Lack, H.W. (1999). The Flora Graeca Story: Oxford's finest botanical treasure. Oxford: Oxford University Press.

Lack, H.W. (2002). Ferdinand, Joseph und Franz Bauer: Testamente, Verlassenschaften und deren Schicksale. Ann. Naturhist. Mus. Wien 104B: 479-551.

Lack, H.W. (2006). Florilegium Imperiale. Botanische Schätze für Kaiser Franz I. von Österreich. München: Prestel.

Lack, H.W. (2008). Franz Bauer. Das gemalte Zeugnis der Natur. Wien: Verlag des Naturhistorisches Museum Wien.

Lack, H.W. (2015). The Bauers, Joseph, Franz \& Ferdinand: Masters of botanical illustration. Munich, London, New York: Prestel.

Lack, H.W. (2016). A garden Eden / Ein Garten Eden / Un jardin d'éden, $3^{\text {rd }}$ edition. Köln: Taschen.

Lack, H.W. \& Mabberley, D.J. (1999). The Flora Graeca Story: Sibthorp, Bauer and Hawkins in the Levant. Oxford: Oxford University Press.

Lasègue, A. (1845). Musée botanique de Benjamin Delessert. Notices sur les collections de plantes et la bibliothèque qui le composent. Paris: Librairie de Fontin, Masson et Cie.

Lazović, Ž., Mitrović, D. \& Šuput, I. (eds) (2017). Universitetsko nasleđe Srbije / The University Heritage of Serbia. Beograd: Universitet u Beogradu. Available at http:// umac.icom.museum/serbian-university.museums-and-collections/. 
Mabberley, D.J. (1999). Ferdinand Bauer: the nature of discovery. London: Merrell Holberton. Mabberley, D.J. (2017). Painting by numbers: the life and art of Ferdinand Bauer. Sydney: University of New South Wales Press.

Nadsona, G.A. (1913). Biblioteka imperatorskago botaničeskago sada. In: Fischer von Waldgejm, A.A. (ed.) Imperatorski S. Peterburgskij Botaničeskij Sad za 200 let ego suščestvovanija (1713-1913), pp. 39-95. Saint Peterburg.

Pfundheller, J. (1881). Der Blumenkaiser: österreichisches Zeit- und Culturbild. Wien: Manz. Pritzel, G.A. (1847a). [7041] Flora graeca. Leipziger Repert. 19: 258-261.

Pritzel, G.A. (1847b). Erinnerungen an Benjamin Delessert. Grenzboten 6: 491-498.

Pritzel, G.A. (1872). Thesaurus literaturae botanicae, $2^{\text {nd }}$ edition. Lipsiae: F.A. Brockhaus.

Rechinger, K.H. (1944). Flora Aegaea. Denkschr. Akad. Wiss. Wien, Math.-Nat. Kl. 105 (1).

Rendle, A.B. (1932). Dr. G. Claridge Druce, F. R. S. Nature 129: 426-427.

Riedl-Dorn, C. (1989). Die grüne Welt der Habsburger. Zur Ausstellung auf Schloß Artstetten 1. April bis 2. November 1989. Veröff. Naturhist. Mus. Wien, N. F., 23. Wien: Naturhistorisches Museum.

Schneckenburger, S. (2015). Die Darmstädter 'Flora Graeca': der einzige Erstdruck des legendären Werks in Deutschland in der Universitäts- und Landesbibliothek Darmstadt. Gärtn. Bot. Brief 198: 14-21.

Schneckenburger, S., Schellhaas, K. \& Uhlemann, S. (2016). Griechenland in Südhessen Die Darmstädter 'Flora Graeca'. Darmstadt: Universitäts- und Landesbibliothek Darmstadt.

Schneider, U.J. \& Vieler, A. (eds.) (2014). Römers Garten. Aus der Pflanzenbuchsammlung der Universitätsbibliothek Leipzig. Schrift. Universitätsbibliothek Leipzig 32. Leipzig: Universitätsbibliothek Leipzig.

Stearn, W.T. (1999). John Lindley's contribution to Sibthorp and Smith's 'Flora Graeca'. Ann. Mus. Goulandris 10: 163-170.

Strid, A. \& Strid, B. (eds.) (2009-2013). Sibthorp \& Smith, Flora Graeca. An annotated reissue 1-5. Königstein: Koeltz.

Swann, C.K. (1972). Natural history bookselling. J. Soc. Bibliogr. Nat. Hist. 6: 118-126.

Tenore, M. (1842). Annotazioni alla Flora Graeca. Rendiconto Accad. Sci. Soc. Borbon. Napoli 1: $82-103$.

Wagenitz, G. (1982). Das Bild der Pflanze in botanischen Werken. Ausstellung im Foyer der Bibliothek anlässlich des 150jährigen Bestehens des Göttinger Universitätsherbars.-s. 1. Kleine Ausstellungsführer. Niedersächsische Staats- und Universitätsbibliothek 9.

Witts, L.J. (1958). Arthur Quinton Wells. J. Path. 75: 495-501.

\section{Unpublished Material}

Vienna, Österreichische Nationalbibliothek, Archiv

FKBA11049. Letter by Peter Thomas Young to Franz I, Emperor of Austria, 15 iv 1828; FKBA 18003. Letter by Leopold von Khloyber to Franz I, Emperor of Austria, 21 i 1834. 


\section{Appendix}

List of Flora Graeca copies kept in libraries on the European continent with shelf marks; abbreviations as given in the text
Copenhagen : $\quad$ Bot 57.13
Darmstadt : $\quad$ gr. Fol. 3/340
Paris, BC : $\quad$ Fonds ancien 91
Paris, BIF : $\quad$ FOL DM 249 Reserve
Paris, BnF : $\quad$ FRBNF31363441
St. Petersburg : Unknown
Vienna, ONB : $\quad$ 181.472-E. Rara 